\title{
Clinical course of untreated cerebral cavernous malformations: individual patient data meta-analysis
}

\author{
Margaret Horne ${ }^{1 *}$, Kelly Flemming ${ }^{2}$, I-Chang Su${ }^{3}$, Christian Stapf ${ }^{4}$, Robert Brown $\mathrm{Jr}^{2}$, Teresa Christianson², \\ Ronit Agid $^{3}$, Karel terBrugge ${ }^{3}$, Robert Willinsky ${ }^{3}$, Susanne Maxwell ${ }^{1}$, Gordon Murray ${ }^{1}$, Rustam Al-Shahi Salman ${ }^{1}$ \\ From 2nd Clinical Trials Methodology Conference: Methodology Matters \\ Edinburgh, UK. 18-19 November 2013
}

\section{Background}

The clinical course of untreated cerebral cavernous malformations (CCM) remains uncertain, partly due to small sample sizes and the infrequency of outcome events in previous studies. The dilemma about whether, when and how to treat patients would be informed by a more precise estimation of clinical course, identification of prognostic factors and derivation of prognostic models.

\section{Method}

From a systematic review, we identified three prospective or retrospective hospital-based cohorts (Mayo Clinic, Rochester, MN; Toronto Western Hospital, Toronto; and Hôpital Lariboisière, Paris) and one prospective population-based cohort (Scotland) that could provide detailed data regarding clinical outcome between diagnosis and CCM treatment or last follow-up in adults with CCM. We will describe baseline characteristics and use survival analysis to calculate the risks of outcomes at specific times and identify their predictors using adjusted hazard ratios. We will pool the estimates from each study in meta-analyses using random-effects models, and quantify and investigate any heterogeneity between studies.

\section{Results}

In three cohorts providing data to date $(n=745)$, between $29 \%$ and $46 \%$ of patients presented incidentally, $20-29 \%$ with seizure, $13-34 \%$ with haemorrhage, and 11$17 \%$ with focal neurological deficit. In follow-up these cohorts identified 105 symptomatic events, including 46 haemorrhages.

\section{Discussion}

A large multinational meta-analysis of CCMs has been initiated. The inclusion of cohorts and their detailed data will be finalised by August 2013, with more than 1,000 patients to be included. We will present our initial results in November 2013. Our findings will help design future studies of the effects of treatment.

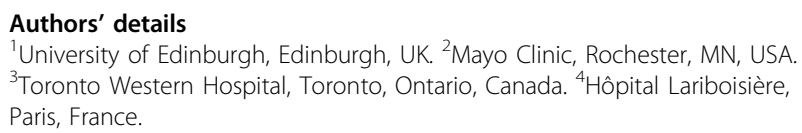

Published: 29 November 2013

doi:10.1186/1745-6215-14-S1-P118

Cite this article as: Horne et al:: Clinical course of untreated cerebral cavernous malformations: individual patient data meta-analysis. Trials 2013 14(Suppl 1):P118.
Submit your next manuscript to BioMed Central and take full advantage of:

- Convenient online submission

- Thorough peer review

- No space constraints or color figure charges

- Immediate publication on acceptance

- Inclusion in PubMed, CAS, Scopus and Google Scholar

- Research which is freely available for redistribution 